\title{
Az artériás érfali merevség és a rendszeres testmozgás kapcsolata
}

\author{
Diószegi Ágnes dr. ${ }^{1}$ - Kovács Beáta dr. ${ }^{2}$ \\ Lengyel Szabolcs dr. ${ }^{2}$ - Szántó Sándor dr. ${ }^{3}$ - Kocsis Erika dr. ${ }^{4}$ \\ Páll Dénes $d r^{2}{ }^{2}$ Harangi Mariann $d r^{1}$
}

${ }^{1}$ Debreceni Egyetem, Általános Orvostudományi Kar, Anyagcsere Betegségek Tanszék, Belgyógyászati Intézet, Debrecen

${ }^{2}$ Debreceni Egyetem, Általános Orvostudományi Kar, Orvosi Klinikai Farmakológiai Tanszék, Debrecen ${ }^{3}$ Debreceni Egyetem, Általános Orvostudományi Kar, Sportorvosi Tanszék, Debrecen

${ }^{4}$ East Surrey Hospital, Redhill, Surrey, United Kingdom

A cardiovascularis megbetegedések kialakulását és progresszióját jelentősen befolyásolja az életmód, ezen belül a fizikai aktivitás. A rendszeres testmozgás csökkenti a szív- és érrendszeri kórképek kockázatát, többek között a magas vérnyomásra, a zsíranyagcsere-eltérésekre és az elhízásra gyakorolt kedvező hatásán keresztül, továbbá független tényező a cardiovascularis halálozás szempontjából is. Az artériás érfali merevség az elasztikus artériák falát alkotó extracelluláris mátrix degeneratív eltéréseinek következtében alakul ki a különböző kockázati tényezők hatására. Korábban, különböző populációkon már igazolták az érfali merevség prediktív értékét a cardiovascularis események kialakulásának tekintetében. A pulzushullám-terjedési sebesség mérése a leggyakrabban alkalmazott módszer az érfali merevség meghatározására. A pulzushullám-terjedési sebesség mérésének hasznát a cardiovascularis kimenetel és élettartam becslésében számos populációs szintű követéses vizsgálat igazolja. Jelen munkánkban áttekintjük a rendszeres fizikai aktivitás, az érfali merevség, az érelmeszesedés és a cardiovascularis események közötti összefüggéseket. Összefoglaljuk az edzésnek és az érfali merevség paramétereinek kapcsolatát egészséges populáción vizsgáló legfontosabb tanulmányok eredményeit. Megállapítjuk, hogy az érfali merevség figyelemre méltó, érdekes biomarker a cardiovascularis kockázat becslése során a rendszeresen sportoló személyek esetén is. Mindezek alapján, tekintve annak prognosztikai hasznát, felmerül a pulzushullám-terjedési sebesség mérésének beillesztése a klinikai döntéshozatali folyamatba mind amatőr, mind professzionális sportolók esetében.

Orv Hetil. 2021; 162(16): 615-622.

Kulcsszavak: testmozgás, érfali merevség, sportoló, cardiovascularis, pulzushullám-terjedési sebesség

\section{Relationship between arterial stiffness and regular physical activity}

The development and progression of cardiovascular disorders is importantly dependent on lifestyle factors, including physical activity. Regular physical activity decreases cardiovascular morbidity by ameliorating risk factors such as hypertension, dyslipidemia and obesity, moreover, also independently affects cardiovascular mortality. Arterial stiffness results from a degenerative process affecting mainly the extracellular matrix of elastic arteries under the effect of risk factors. Previously, the independent predictive value of arterial stiffness for cardiovascular events has been demonstrated in various populations. Pulse wave velocity is the most commonly used method for the assessment of arterial stiffness. The value of measuring pulse wave velocity to predict cardiovascular health outcomes and longevity has been established in several population-based longitudinal studies. In this review, we summarize the main associations between regular physical exercise, arterial stiffness, atherosclerotic burden and incident cardiovascular events. We cite findings from the major studies focusing on the effect of training on arterial stiffness parameters in healthy subjects. We conclude that arterial stiffness is emerging as an interesting biomarker for cardiovascular risk stratification in subjects doing regular physical activity. Therefore, the incorporation of pulse wave velocity measurement into clinical decision-making could be indicated in the case of both amateur and professional athletes, given the prognostic information it provides.

Keywords: physical activity, arterial stiffness, professional athlete, cardiovascular, pulse wave velocity

Diószegi Á, Kovács B, Lengyel Sz, Szántó S, Kocsis E, Páll D, Harangi M. [Relationship between arterial stiffness and regular physical activity]. Orv Hetil. 2021; 162(16): 615-622.

(Beérkezett: 2020. szeptember 15.; elfogadva: 2020. október 21.) 


\section{Rövidítések}

ANGPTL4 = (angiopoietin-like protein 4) angiopoietinszerú fehérje-4; $\mathrm{BDNF}=$ (brain-derived neurotrophic factor $)$ agyi eredetû́ növekedési faktor; $\mathrm{CPET}=($ cardiopulmonary exercise testing) cardiopulmonalis terheléses vizsgálat; cSBP $=$ (central systolic blood pressure) centrális systolés vérnyomás; ELISA = (enzyme-linked immunosorbent assay) enzimhez kapcsolt immunszorbens-vizsgálat; FGF21 = (fibroblast growth factor 21) fibroblastnövekedési faktor-21; FMD = (flow-mediated vasodilation $)$ áramlás mediálta vasodilatatio; FSTLl = (follistatinlike protein 1) follisztatinszerü fehérje-1; IL = interleukin; LIF $=$ (leukemia inhibitor factor) leukaemiagátló faktor; $\mathrm{MMP}=$ mátrixmetalloproteináz; $\mathrm{NO}=$ nitrogén-monoxid; oxLDL = (oxidized low-density lipoprotein) oxidált alacsony sürúségú lipoprotein; $\mathrm{pSBP}=$ (peripheral systolic blood pressure) perifériás systolés vérnyomás; TIMP $=$ (tissue inhibitors of metalloproteinase) a mátrixmetalloproteinázt gátló szöveti inhibitor; $\mathrm{TNF} \alpha=$ tumornekrózisfaktor-alfa; VEGF $=$ vascularis endothelialis növekedési faktor

Az iparilag fejlett országokban a mortalitás egyik vezető oka a szív- és érrendszeri megbetegedések csoportja. Ismert, hogy a rendszeres testmozgás 35\%-kal csökkenti a cardiovascularis eredetû halálozást, valamint 33\%-kal mérsékli az összhalálozást is [1]. A rendszeres testedzés jótékony hatása magyarázható egyfelől az ismert kockázati tényezők kedvezőbbé válásával [2], illetve hatása van hemodinamikai paraméterekre is [3]. Javítja az endothelfunkciót a nitrogén-monoxid (NO) mediálta vasodilatatión keresztül. Kingwell és mtsai kimutatták, hogy már négyheti rendszeres kerékpározás növelte a bazális NO-termelést, ezáltal javult az áramlás mediálta vasodilatatiós (FMD) kapacitás is [4]. Úgy tûnik tehát, hogy a mozgás egyértelműen kedvező a szív- és érrendszeri megbetegedések szempontjából, ennek mechanizmusát illetően azonban számos nyitott kérdésre keresik a választ. Az alábbiakban a fizikai aktivitás és az érfali merevség összefüggéseit tekintjük át, összefoglalva a patomechanizmus leglényegesebb elemeit, valamint a legfontosabb klinikai vizsgálatok és metaanalízisek adatait.

\section{Az érfali merevség patomechanizmusa és klinikai jelentősége}

A cardiovascularis mortalitás önálló kockázati tényezője az artériás érfali merevség [5]. A jelenség az ütőerek falát érintő komplex folyamat, mely az érfal szerkezetét és múködését is módosítja. Az érfalat érintő gyulladásos folyamatok, a megjelenő gyulladásos citokinek és az oxidatív stressz hatására az érfal számos szerkezeti eleme, de fóként az extracelluláris mátrix degradálódik, enzimatikus folyamatok, elsősorban a mátrixmetalloproteináz (MMP)-aktivitás fokozódása, illetve az ezt gátló szöveti inhibitorok (TIMP) aktivitásának csökkenése következtében az elasztikus rostok feldarabolódnak, keresztkötések alakulnak ki, és a rostok elmeszesednek. A mátrixot alkotó fehérjék poszttranszlációs modifikációja, ezen belül a nem enzimatikus glikáció és az izomerizáció ugyancsak elősegíti a funkcionális változások kialakulását. Ez-

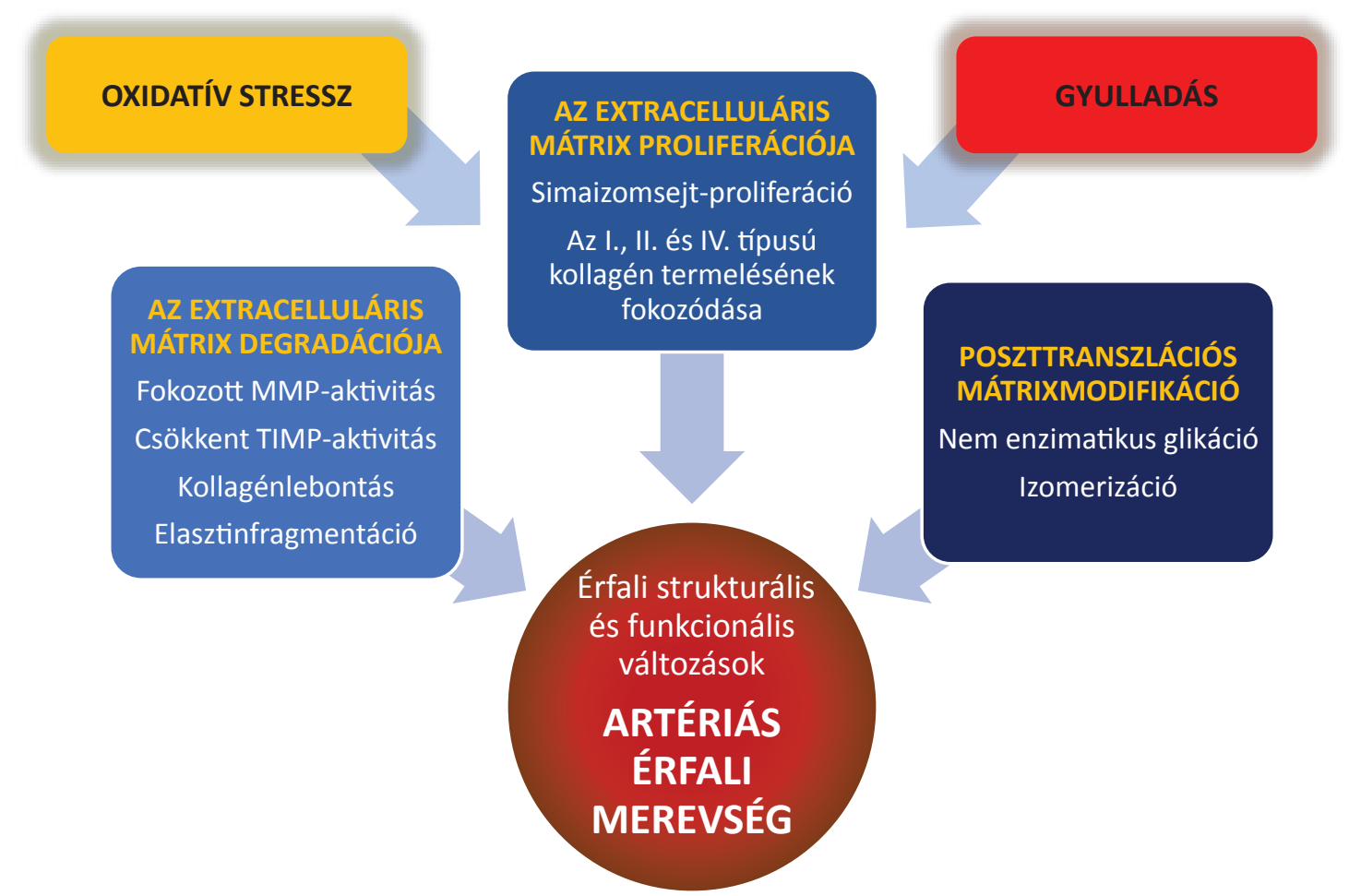

\begin{tabular}{l|l} 
1. ábra & Az artériás érfali merevség patomechanizmusának legfontosabb tényezói \\
MMP = mátrixmetalloproteináz; TIMP = a mátrixmetalloproteinázt gátló szöveti inhibitor
\end{tabular} 
zel párhuzamosan az érfali I., II. és IV. típusú kollagén de novo szintézise fokozódik. A simaizomsejtek proliferációja kulcsszerepet játszik a folyamatban, mivel elsődlegesen ezek a sejtek felelősek az extracelluláris mátrix egyes komponenseinek termeléséért [6]. Az érfali merevség patomechanizmusát az 1 . ábra foglalja össze [7]. Bár az elváltozások a teljes artériás érrendszert érintik, mégis a legkifejezettebben az aortoiliacalis szakaszon figyelhetők meg, melyek elasztikus rostokban a leggazdagabb érszakaszok, és kevésbé jellemzőek a perifériás érszakaszokon [8].

Az érfali merevség önmagában az életkorral fokozódik, mégsem azonos a vascularis öregedés fogalmával [9], mivel ezt a folyamatot számtalan egyéb tényező befolyásolja jelentős mértékben, köztük az oxidatív stressz [9]. Az oxidatív stressz csökkentése által a rendszeres testmozgás mérsékli az öregedés okozta fokozott érfali merevséget $[10,11]$. Kimutatták, hogy 20-35\%-kal csökkent az érfali merevség azoknál az egyéneknél, akik rendszeres testmozgást végeztek [12]. Az érfali merevség vizsgálata azért is kiemelten fontos, mert igazolták, hogy a szubklinikai atherosclerosis egyik korai jele lehet [13-15].

\section{Az érfali merevség meghatározása}

Az érfali merevséget a leggyakrabban a pulzushullámterjedési sebességgel jellemzik, amely az artéria adott szakasza hosszának és a pulzus ezen szakaszon mért tovaterjedési idejének hányadosaként határozható meg [13]. A leginkább a carotis-femoralis pulzushullám-terjedési sebesség mérése elfogadott, mely a centrális érfali merevség jellemzésének standard mérőszáma, valamint a cardiovascularis események és halálozás prediktora nagy populáción elvégzett követéses vizsgálatok alapján [16]. Mivel a bal kamra az aortát és annak fóágait látja el közvetlenül, ezáltal ez a szakasz felelős az erek pufferkapacitásának legnagyobb részéért, valamint ez az érelmeszesedés által leginkább érintett szakasz; a carotis-femoralis pulzushullám-terjedési sebességének mérése ajánlott, fóként a kutatási céllal végzett mérések esetén. A klinikai gyakorlatban azonban a femoralis-boka, illetve brachialis-boka pulzushullám-terjedési sebesség értékeinek meghatározását is alkalmazzák, ami gyakran nehezíti az egyes tanulmányok értékelését és összehasonlítását [17]. A pulzushullám-terjedési sebesség annál magasabb érték, minél fokozottabb az érfali merevség. Egy 17 követéses vizsgálatot magában foglaló metaanalízis alapján a pulzushullám-terjedési sebesség $1 \mathrm{~m} / \mathrm{s}$-mal magasabb értéke a cardiovascularis esemény 14\%-kal nagyobb kockázatával, 15\%-kal nagyobb cardiovascularis halálozással és 15\%-kal nagyobb összhalálozási rizikóval jár [18].

A pulzushullám-terjedési sebesség mérésére számos módszert fejlesztettek ki, ezen belül oszcillometriás, tonometriás, volumenpletizmográfiás és fotopletizmográfiás készülékek érhetők el, de a pulzushullám-terjedési sebesség meghatározásának széles körben elfogadott, standard metodikája az applanációs tonometria [13]. A klinikai gyakorlatban való elterjedése annak köszönhető, hogy noninvazív, könnyen reprodukálható és gyors vizsgálómódszerról van szó.

Az utóbbi évek fejlesztéseinek következében az egyszeri mérés mellett lehetôség nyílt a centrális artériás vérnyomás 24 órás ambuláns mérésére is [19], mely minden bizonnyal további információkkal szolgálhat a fizikai aktivitásnak az érfali merevség paramétereire gyakorolt hatásairól.

Számos tanulmány foglalkozott a rendszeres testmozgás és a pulzushullám-terjedési sebesség kapcsolatával egészséges egyének, élsportolók, illetve krónikus betegek esetében. Továbbá vizsgálták, hogy az aerob és anaerob mozgások hogyan befolyásolják a pulzushullám-terjedési sebességet.

\section{Aerob és anaerob mozgásformák hatása a pulzushullám-terjedési sebességre}

Abmadi-Abgari és mtsai a Whitehall II. tanulmány során a fizikai aktivitás szerepét vizsgálták az érfali merevség progressziójában. 5196 fö bevonásával vizsgálták az önbevallás alapján felmért fizikai aktivitás hatását 65 , illetve 70 éves korban, valamint 6 és 11 évvel azt megelőzően. Az eredmények alapján minden óra/hét közepes és intenzív fizikai aktivitás az 5 éves carotis-femoralis pulzushullám-terjedési sebesség átlagosan $0,02 \mathrm{~m} / \mathrm{s}$-mal alacsonyabb progressziójával társult, míg a fizikai aktivitás hiányában a carotis-femoralis pulzushullám-terjedési sebesség 5 éves progressziója $0,007 \mathrm{~m} / \mathrm{s}-\mathrm{mal}$ növekedett. A megnövelt fizikai aktivitás $0,16 \mathrm{~m} / \mathrm{s}-\mathrm{mal}$ csökkentette a carotis-femoralis pulzushullám-terjedési sebesség 5 éves progresszióját [20].

Ashor és mtsai metaanalízise 42 randomizált, kontrollált tanulmány eredményeit foglalja össze [21]. A beválasztási kritériumok közül kiemelhető a négy héten át folytatott, rendszeres fizikai aktivitás, valamint az, hogy az érfali merevség paramétereit a vizsgálat kezdetekor és végén is meghatározták. A beválasztott önkéntesek minden esetben betöltötték a 18. életévüket. A tanulmány 1627 résztvevő adatait dolgozta fel (801 férfi és 826 nő). Átlagéletkoruk 47 év volt (19-72 év). A vizsgálatok átlagidőtartamát 12 hétben (4-52 hét) határozták meg. 20 tanulmány aerob, 14 pedig anaerob mozgásformát, illetve 12 ezek kombinációját vizsgálta. A metaanalízis döntően egészséges, krónikus betegségben nem szenvedő egyének adatait dolgozta fel. Kis esetszámban diabeteses, hypertoniás vagy krónikus veseelégtelenek is szerepeltek a vizsgálatokban. Az aerob mozgásformák esetén azt találták, hogy azoknál az egyéneknél, akiknél a kiindulási pulzushullám-terjedési sebesség értéke magasabb (>8 m/s) volt, jelentösen nagyobb mértékben csökkent a pulzushullám-terjedési sebesség, ezáltal szignifikánsan javult az érfali merevség is. Azokban az esetekben, amelyeknél legalább 10 hétig végeztek rendszeres testmozgást, az érfali merevség javulása szignifikánsan magasabb 
volt. Nem volt kimutatható szignifikáns korreláció a szívfrekvencia és a vérnyomásváltozás, valamint a pulzushullám-terjedési sebesség csökkenése között. Az anaerob mozgásformák esetén összességében elmondható, hogy szignifikánsan nem befolyásolták a pulzushullám-terjedési sebesség értékét. Kombinált edzésformák esetén szignifikáns javulás nem volt kimutatható a pulzushullám-terjedési sebesség értékében. Összességében elmondható, hogy Ashor és mtsai kimutatták: a pulzushullám-terjedési sebesség szignifikáns csökkenésében az aerob mozgásformáknak van szerepük. Eredményeik azt támasztják alá, hogy a cardiovascularis mortalitást sikeresen javíthatja a rendszeres aerob mozgás [21].

Shibata azt vizsgálta, hogy a különböző frekvenciájú, de rendszeres, élethosszig tartó testmozgás hogyan befolyásolja a érfali merevség paramétereit [11]. A vizsgálatban részt vevő 102,60 év feletti egyént négy csoportba osztották a sportolási gyakoriság frekvenciája alapján. Az ülő életmódúak kategóriájába $(\mathrm{n}=27)$ sorolták azokat, akik hetente egyszer vagy egyszer sem sportoltak. Alkalmi sportolónak $(\mathrm{n}=25)$ számított, aki hetente kétszer vagy háromszor sportolt, elhivatottnak $(\mathrm{n}=25)$, aki hetente négyszer vagy ötször sportolt. Az élsportolói kategóriába $(n=25)$ azok kerültek, akik hetente hétszer edzettek, és rendszeresen indultak versenyeken. A centrális pulzushullám-terjedési sebességet (carotis-femoralis pulzushullám-terjedési sebesség) SphygmoCor (Atcor Medical, Sydney, Ausztrália) segítségével határozták meg. Eredményeik azt mutatták, hogy az ülő életmódú csoportnak szignifikánsan magasabb $(\mathrm{p}=0,016)$ volt a vérnyomása a másik három csoporthoz viszonyítva. A centrális pulzushullám-terjedési sebesség szignifikánsan alacsonyabb ( $\mathrm{p}=0,066)$ volt az élsportolók és az elhivatottak kategóriájában, mint az ülő életmódúak és az alkalmi sportolók között. Összegzésként elmondható, hogy a rendszerességen kívül a sportolás frekvenciája is befolyásolja a pulzushullám-terjedési sebesség változását, az érfali merevséget.

Burr és mtsai a magas intenzitású CrossFit-edzés hatását vizsgálták az érfali merevség paramétereire. A CrossFit-edzés az aerob és az anaerob, rezisztenciaedzés keveréke. A vizsgálatba 30 egyént vontak be, három csoportra osztva őket: mindegyik csoportba 10 fö került. $\mathrm{Az}$ első csoportba a CrossFit-esek kerültek, a második csoportot a rendszeresen aerob mozgást folytató, aktív kontrollcsoport képezte, míg a harmadik csoportot az ülő életmódot folytató, passzív kontrollcsoport alkotta. Vizsgálatuk kimutatta, hogy a CrossFit-csoport és az aktív kontrollcsoport között nem volt szignifikáns eltérés a pulzushullám-terjedési sebesség tekintetében. Ugyanakkor a pulzushullám-terjedési sebesség mind a CrossFit-, mind pedig az aktív kontrollcsoport esetében szignifikánsan alacsonyabb volt a passzív kontrollokhoz képest [22].

A rezisztenciatréning - az aerob mozgásformákkal ellentétben - a szimpatikus idegrendszeri aktiváció miatt az edzés során jelentős vérnyomás-emelkedést okoz, így a fokozott érfali feszülés következtében kedvezőtlen hatású lehet az érfali merevség kialakulása szempontjából [23]. Egy korábbi, Miyachi által végzett metaanalízis a pulzushullám-terjedési sebességnek a rezisztenciatréning hatására bekövetkező 11\%-os emelkedését írta le [24], míg egy másik, Evans és mtsai által közölt feldolgozás nem talált szignifikáns változást [25]. Nemrégiben Ceciliato és mtsai - áttekintve az irodalmi adatokat a rezisztenciatréning hatásáról az érfali merevség paramétereire egészséges egyénekben - azt találták, hogy a vizsgált tíz tanulmány 310 résztvevőjének (194 fó a tréningcsoportban, 116 kontroll) adatai alapján a rezisztenciatréning nem eredményezett szignifikáns változást a pulzushullám-terjedési sebesség értékeiben, bár a nagy egyéni variabilitás miatt további vizsgálatok elvégzését javasolták [26].

Sardeli és mtsai a különböző mozgásformáknak a centrális érfali merevségre gyakorolt eltérő azonnali, rövid és hosszú távú hatásaira hívták fel a figyelmet egy átfogó, 56 tanulmány adatait feldolgozó metaanalízis adatai alapján. Kiemelték, hogy az aerob mozgásformák hatása hosszú távon kedvező, míg az anaerob, rezisztenciatréningek kedvezőtlen hatást gyakorolnak a centrális érfali merevség paramétereire rövid és hosszú távon egyaránt. A kombinált mozgásformák hatása rövid távon nem szignifikáns, míg a hosszú távú hatások tekintetében nem áll rendelkezésre megfelelő mennyiségú adat [27].

Nemcsak a mozgás típusa, hanem annak intenzitása, illetve a vizsgált személy életkora is lényeges tényező Figueroa és mtsai vizsgálata alapján. A nagy intenzitású rezisztenciatréning fiataloknál és időseknél egyaránt emelte vagy nem befolyásolta a carotis-femoralis pulzushullám-terjedési sebesség és a femoralis-boka pulzushullám-terjedési sebesség értékeit; a brachialis-boka pulzushullám-terjedési sebesség a fiataloknál nőtt vagy nem változott, míg az időseknél csökkenést észleltek. Az alacsony intenzitású rezisztenciaedzés fiataloknál a brachialis-boka pulzushullám-terjedési sebesség csökkenését eredményezte, míg időseknél a carotis-femoralis pulzushullám-terjedési sebesség nőtt vagy nem változott, ám a femoralis-boka, illetve brachialis-boka pulzushullámterjedési sebesség nem változott szignifikánsan. Ugyanakkor a rezisztenciatréning az életkortól és az intenzitástól függetlenül csökkentette a centrális és perifériás vérnyomásértékeket. Mindez felhívja a figyelmet az egyénre szabott mozgásformák fontosságára [28].

Mindössze egy, kevés résztvevő bevonásával készült tanulmány vizsgálta az edzés hatását az artériás érfali merevség paramétereire 24 órás ambuláns készülék (MobilO-Graph; Numed Healthcare, Sheffield, Egyesült Királyság) alkalmazásával. Goeder és mtsai 25 egészséges férfi bevonásával azt igazolták, hogy kerékpár-ergométerrel végzett cardiopulmonalis terheléses vizsgálat (CPET) elvégzését követően a centrális szisztolés vérnyomás (cSBP) szignifikánsan csökkent az edzést követő 1., 2. és 3. órában. Ezt követően a cSBP fokozatosan 
emelkedett, de elmaradt a kiindulási értéktől. Ezzel szemben a perifériás szisztolés vérnyomás (pSBP) csak az edzést követően 10 órával csökkent, ami arra utal, hogy a fizikai aktivitás hatása eltérő a centrális és a perifériás artériás rendszerre [29].

\section{Élsportolók és az érfali merevség vizsgálata}

$\mathrm{Az}$ élsport cardiovascularis kockázatra kifejtett hatása széles körben vizsgált terület, mégis több nyitott kérdés vár válaszra. Számos vizsgálat igazolta, hogy az élsportolók esetén a koszorúér-meszesedés folyamata felgyorsul, ennek ellenére a cardiovascularis események kockázata kisebb, és a túlélés is jobb ebben a csoportban, amit a kedvezőbb plakkösszetétellel és a fizikai aktivitás indukálta adaptációs folyamatokkal magyaráznak [30]. Az érfali merevség paramétereinek és az élsportnak a tekintetében azonban kevés az adat.

Koshiba és mtsai 18 fiatal nőt vizsgáltak, közülük 8 aktív élsportoló, 10 pedig az élsporttól visszavonult, de aktívan sportoló egyén volt. 12 hónapos követéses vizsgálat során a kiindulási pont a visszavonulás időpontja volt, majd 1, 2, 3, 6 és 12 hónap múlva vizsgálták a pulzushullám-terjedési sebesség változását mindkét csoport esetén. Kiinduláskor és az első két hónapban szignifikáns különbség nem volt észlelhető a két csoport tagjai között. A harmadik hónap során szignifikánsan alacsonyabb volt a pulzushullám-terjedési sebesség az aktív sportolók esetében, és ez a szignifikáns különbség tartósan kimutatható volt a 12. havi kontrollmérés esetén is [31].

\section{Hogyan befolyásolja a fizikai aktivitás az artériás érfali merevség paramétereit?}

A klinikai vizsgálatok eredményei időnként jelentősen eltérnek, ami a bevont vizsgálati populáció heterogenitása, a fizikai aktivitás eltérő jellege, intenzitása és tartalma mellett a hatás komplex jellegével magyarázható. A fizikai aktivitás legnyilvánvalóbb eredménye és egyben célja az izomtömeg növelése és a fehér zsírszövet mennyiségének csökkentése. Mindez kedvező hatást gyakorol a szénhidrátháztartásra, csökkentve az inzulinrezisztenciát, fokozva ezzel a glükózfelvételt, ami csökkenti a fehérjék glikációját. A fehér zsírszövet által termelt proinflammatorikus adipokinek, köztük a leptin, a rezisztin, a tumornekrózisfaktor-alfa (TNF $\alpha)$ szintje csökken, míg az antiinflammatorikus adipokinek - például az adiponektin és a fibroblastnövekedési faktor-21 (FGF21) szintje nő. Ennek hatására a krónikus, alacsony fokú gyulladás mértéke csökken, ami az IL6, az IL10 és a keringő TNF $\propto$ szintjének csökkenésében is lemérhető [32]. Mindez az oxidatívstressz-mértékek csökkenéséhez vezet, ami emeli a NO szintjét, és csökkenti a MMP-aktivitást. Ezen hatásokat azonban genetikai és környezeti faktorok, társbetegségek, gyógyszerek és számos egyéb tényező befolyásolja, beleértve a szimpatikus idegrendszer múködését befolyásoló stresszt. Ezért a populációs szinten érvényes kedvező hatás az egyén szintjén gyakran nem nyilvánvaló, ami felhívja a figyelmet az egyéni érfali merevség méréseinek hasznára egy-egy mozgásfor-

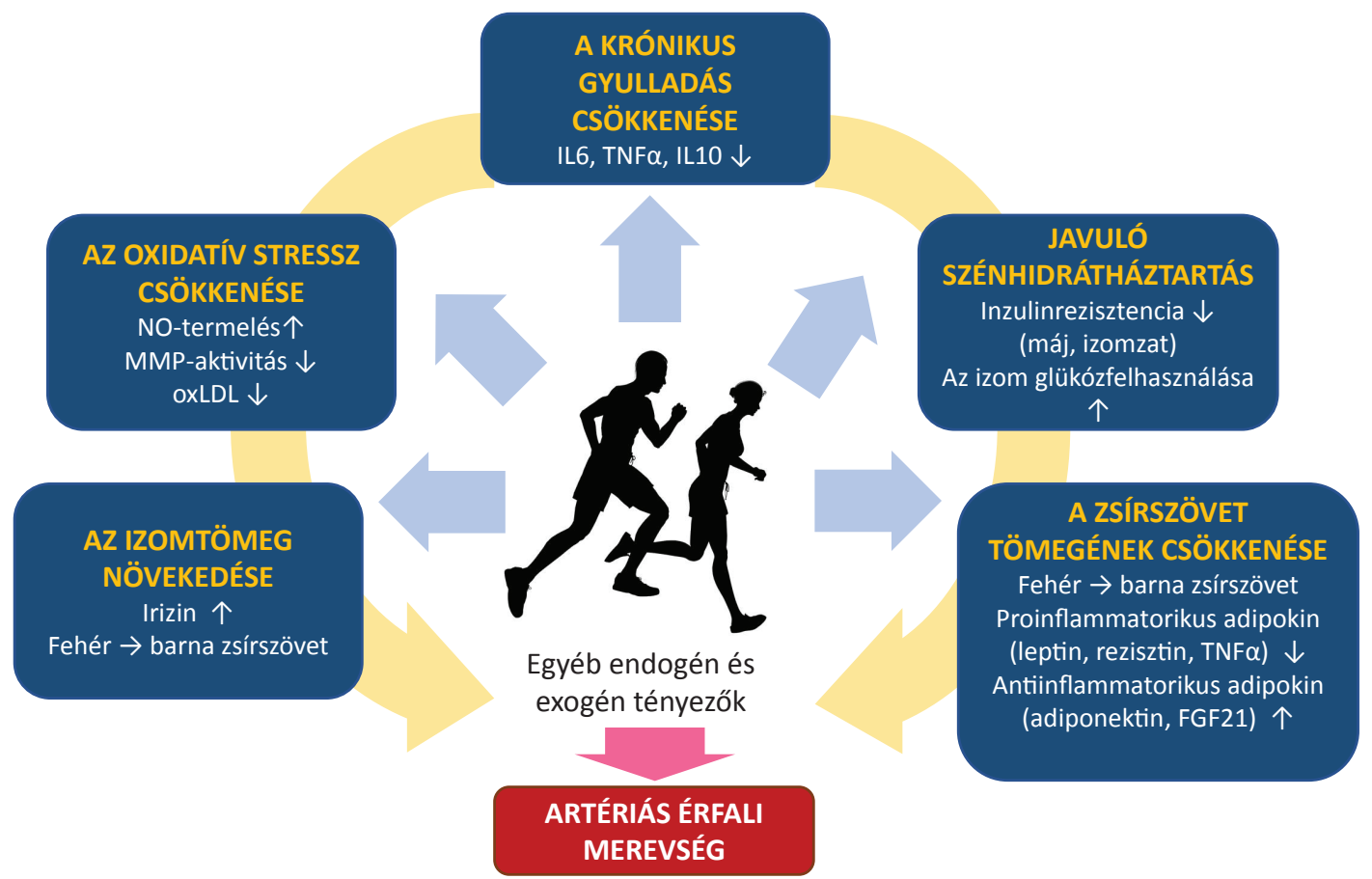

2. ábra

A fizikai aktivitás komplex hatása az artériás érfali merevség kialakulására

FGF21 = fibroblastnövekedési faktor-21; IL = interleukin; MMP = mátrixmetalloproteináz; NO = nitrogén-monoxid; oxLDL = oxidált alacsony sürüségű lipoprotein 
ma esetén, amatőr és profi sportolóknál egyaránt. A fizikai aktivitás komplex hatását az érfali merevség kialakulására a 2. ábra szemlélteti.

\section{A biológiai markerek és az érfali merevség kapcsolata}

Az érfali merevség kialakulásában szerepet játszó bioaktív fehérjék szintjének meghatározása további segítséget nyújthat az adott fizikai aktivitás hatásának értékelésében. Sajnos kevés, a mindennapi klinikai gyakorlatban is használható biomarker áll rendelkezésre. Az izom-öszszehúzódás által szabályozott, elsősorban a zsír- és izomszövet által termelt, ún. adipomiokinek szerepét azonban egyre szélesebb körben vizsgálják. Idetartozik a már említett FGF21 mellett az angiopoietinszerü fehérje-4 (ANGPTL4), az agyi eredetű növekedési faktor (BDNF), a follisztatinszerü fehérje-1 (FSTL1), számos interleukin (IL6, IL7, IL15), az irizin, a leukaemiagátló faktor (LIF), a mionektin, a miosztatin és a vascularis endothelialis növekedési faktor (VEGF) [33], melyek termelődését a fizikai aktivitás alapvetően meghatározza.

Állatmodellekben kimutatták, hogy az FGF21-nek védőszerepe van a vascularis remodelling során [34]. Igazolták, hogy a cardiovascularis betegségben szenvedőkben az FGF21 koncentrációja magasabb [35]. Lee és mtsai az oxidatív stressz és a pulzushullám-terjedési sebesség kapcsolatát vizsgálták az öregedés és a rendszeres testmozgás vonatkozásában. Vizsgálatukba 80 résztvevőt vontak be, akiket négy részre osztottak: fiatal aktív (18-36 év), fiatal passzív, idős aktív (45-80) és idős paszszív csoportokat hoztak létre. Meghatározták az FGF21, az oxidált alacsony sűrüségû lipoprotein (oxLDL) és az adiponektin koncentrációját ELISA-módszerrel. Az érfali merevség vizsgálatát SphygmoCorral végezték, 3-5 mérés eredményét átlagolták. Az FGF2l és az adiponektinkoncentráció vonatkozásában nem találtak szignifikáns különbséget a különböző csoportok között. Ugyanakkor az oxLDL szérumkoncentrációja az idős aktív és passzív csoportban szignifikánsan magasabb volt, mint a fiatal aktív és passzív csoportban, de a fizikai aktivitás és az oxLDL szérumszintje közötti szignifikáns korreláció nem volt kimutatható. A pulzushullám-terjedési sebesség szignifikánsan magasabb volt az idős csoportokban a fiatal csoportokhoz viszonyítva, ugyanakkor a pulzushullám-terjedési sebesség és a testmozgás között nem volt pozitív korreláció. Pozitív szignifikáns korreláció volt kimutatható a pulzushullám-terjedési sebesség és az oxLDL között. A pulzushullám-terjedési sebesség és az adiponektinkoncentráció negatív szignifikáns korrelációban álltak. Az FGF21 és pulzushullám-terjedési sebesség tekintetében szignifikáns korrelációt nem találtak. Ezen eredmények alátámasztják, hogy az oxidatív stressz az életkor előrehaladtával fokozódik, ami az érfali merevséget fokozza, még egészséges egyénekben is [36]. Egy másik vizsgálatban Inoue és mtsai azt igazolták, hogy elhízott betegek aerob edzését követően az irizin fokozott termelése összefüggést mutatott az érfali merevség paramétereinek javulásával, ezen belül a carotis-femoralis pulzushullám-terjedési sebesség csökkenésével [37]. A néhány, biztató eredményű tanulmány ellenére a laboratóriumi biomarkerek alkalmazása kezdeti szakaszban jár annak vizsgálatában, hogy a fizikai aktivitás milyen hatékonyságot fejt ki az érfali merevség paramétereire, alkalmazásuk a klinikai gyakorlatban jelenleg nem ajánlott.

\section{Következtetések}

Az irodalmi adatok alapján elmondható, hogy az aerob mozgásformák hatékonyan javítják a pulzushullám-terjedési sebességet, valamint hogy a pulzushullám-terjedési sebesség csökkenése annál nagyobb, minél hosszabb távú az aerob testmozgás, illetve minél magasabb volt a pulzushullám-terjedési sebesség kiindulási értéke [11]. Emellett megállapítható, hogy minél magasabb intenzitású az edzés, annál inkább csökkenti az érfali merevséget $[38,39]$.

A rezisztenciatréning és a pulzushullám-terjedési sebesség kapcsolatáról megoszlanak az irodalmi adatok: Miyachi 2013-ban publikált metaanalízise egyértelmúen amellett foglal állást, hogy a rezisztenciaedzések fokozzák az érfali merevséget [24], ugyanakkor Ashor és mtsai 42 tanulmányt magában foglaló metaanalízise alapján a rezisztenciaedzések nem befolyásolják az érfali merevség paramétereit [21]. A kombinált mozgásformák közül a magas intenzitású CrossFit-edzések esetében kimutatták, hogy nem befolyásolták az érfali merevség paramétereit [22]. Mindezek alapján az Amerikai Sporttudományok Kollégiuma ajánlásban fogalmazta meg, hogy a magas intenzitású aerob edzések preferáltak a szív- és érrendszer egészségének megőrzése érdekében $[40,41]$.

Kevés adat áll rendelkezésre arról, hogy a különböző sportágak élsportolói esetében a fokozott fizikai terhelés hogyan befolyásolja az érfali merevség paramétereit. Felvetődik a kérdés, hogy az élsport befejezését követő 5 év elteltével van-e szignifikáns különbség az érfali merevség paramétereit tekintve a korban, nemben illesztett, krónikus betegségtől mentes, de rendszeresen edző kontrollcsoport és a korábbi élsportolók között, és ez jár-e szignifikánsan alacsonyabb cardiovascularis morbiditással. A korábbi vizsgálatok ugyanakkor alátámasztották, hogy a pulzushullám-terjedési sebesség $1 \mathrm{~m} / \mathrm{s}$-mal való emelkedése 12-14\%-kal emeli a cardiovascularis események előfordulási gyakoriságát, valamint 13-15\%-kal növeli a cardiovascularis mortalitást $[18,42]$.

A kérdéskör egységes értékelésének korlátját a kisszámú, igen eltérô területet vizsgáló, változó színvonalú közlemény jelenti, ami az ehhez hasonló határterületi kutatási témák esetén nem ritka, de határozott és végleges következtetések levonását nem teszi lehetővé. A fizikai aktivitás és az érfali merevség kapcsolatának teljes körü tisztázásához ezért további, nagy betegszámú vizsgálatra lenne szükség validált készülékek és azonos típusú módszerek alkalmazásával, jól definiált vizsgálati po- 
pulációk bevonásával, az adott mozgásforma minél pontosabb leírásával, lehetóleg a már hasznosnak ítélt laboratóriumi biomarkerek párhuzamos meghatározásával. Mindez alátámaszthatja az érfali merevség mint biomarker jelentôségét a cardiovascularis kockázatbecslés során rendszeresen sportolók esetén. Emellett felmerül az érfali merevség paraméterei mérésének beillesztése a klinikai döntéshozatali folyamatba az adott egyén esetén a számára rövid és hosszú távon is legmegfelelőbb és legbiztonságosabb mozgásforma kiválasztásában, ami fontos lehet az amatőr és a professzionális sportolók esetén egyaránt.

Anyagi támogatás: A publikáció elkészítését a GINOP2.3.2-15-2016-00062. számú projekt támogatta.

Szerzői munkamegosztás: D. Á. a szakirodalmi adatok feldolgozásában, K. B., L. Sz. és K. E. a kézirat szerkesztésében, H. M. az ábrák elkészítésében és a kézirat összeállításában, Sz. S. és P. D. a végső változat ellenőrzésében múködött közre. A cikk végleges változatát valamennyi szerző elolvasta és jóváhagyta.

Érdekeltségek: A szerzőknek nincsenek érdekeltségeik.

\section{Irodalom}

[1] Nocon M, Hiemann T, Müller-Riemenschneider F, et al. Association of physical activity with all-cause and cardiovascular mortality: a systematic review and meta-analysis. Eur J Cardiovasc Prev Rehabil. 2008; 15: 239-246.

[2] Mora S, Cook N, Buring JE, et al. Physical activity and reduced risk of cardiovascular events: potential mediating mechanisms. Circulation 2007; 116: 2110-2118.

[3] Green DJ, Maiorana A, O'Driscoll G, et al. Effect of exercise training on endothelium-derived nitric oxide function in humans. J Physiol. 2004; 561(Pt 1): 1-25.

[4] Kingwell BA, Sherrard B, Jennings GL, et al. Four weeks of cycle training increases basal production of nitric oxide from the forearm. Am J Physiol. 1997; 272(3 Pt 2): H1070-H1077.

[5] Lacolley P, Regnault V, Segers P, et al. Vascular smooth muscle cells and arterial stiffening: relevance in development, aging, and disease. Physiol Rev. 2017; 97: 1555-1617.

[6] Lacolley P, Regnault V, Avolio AP. Smooth muscle cell and arterial aging: basic and clinical aspects. Cardiovasc Res. 2018; 114: 513-528.

[7] Kucharska-Newton AM, Stoner L, Meyer ML. Determinants of vascular age: an epidemiological perspective. Clin Chem. 2019; 65: 108-118.

[8] Fortier C, Agharazii M. Arterial stiffness gradient. Pulse (Basel) 2016; 3: 159-166.

[9] Donato AJ, Eskurza I, Silver AE, et al. Direct evidence of endothelial oxidative stress with aging in humans: relation to impaired endothelium-dependent dilation and upregulation of nuclear factor-кB. Circ Res. 2007; 100: 1659-1666.

[10] Madden KM, Lockhart C, Cuff D, et al. Short-term aerobic exercise reduces arterial stiffness in older adults with type 2 diabetes, hypertension, and hypercholesterolemia. Diabetes Care 2009; 32: 1531-1535.

[11] Shibata S, Fujimoto N, Hastings JL, et al. The effect of lifelong exercise frequency on arterial stiffness. J Physiol. 2018; 596 $2783-2795$
[12] Tanaka H, Dinenno FA, Monahan KD, et al. Aging, habitual exercise, and dynamic arterial compliance. Circulation 2000; 102: 1270-1275.

[13] Cavalcante JL, Lima JA, Redheuil A, et al. Aortic stiffness: current understanding and future directions. J Am Coll Cardiol. 2011; 57: 1511-1522.

[14] Cohn JN, Quyyumi AA, Hollenberg NK, et al. Surrogate markers for cardiovascular disease: functional markers. Circulation 2004; 109(25 Suppl 1): IV31-IV46.

[15] Nemcsik J, Tislér A, Kiss I. Clinical value and measurement of arterial stiffness for the assessment of cardiovascular risk in light of recent results. $[\mathrm{Az}$ artériás érfalmerevség cardiovascularis kockázatértéke és mérése a legújabb eredmények tükrében.] Orv Hetil. 2015; 156: 211-215. [Hungarian]

[16] Ben-Shlomo Y, Spears M, Boustred C, et al. Aortic pulse wave velocity improves cardiovascular event prediction: an individual participant meta-analysis of prospective observational data from 17,635 subjects. J Am Coll Cardiol. 2014; 63: 636-646.

[17] Járai Z, Kolossváry E, Szabó I, et al. The potential role of oscillometric devices for ankle-brachial index measurements in clinical practice. [A boka-kar index oszcillometriás elven múködő meghatározásának helye a klinikai gyakorlatban.] Orv Hetil. 2018; 159: 176-182. [Hungarian]

[18] Vlachopoulos C, Aznaouridis K, Stefanadis C. Prediction of cardiovascular events and all-cause mortality with arterial stiffness: a systematic review and meta-analysis. J Am Coll Cardiol. 2010; 55: 1318-1327.

[19] Omboni S, Posokhov IN, Kotovskaya YV, et al. Twenty-fourhour ambulatory pulse wave analysis in hypertension management: current evidence and perspectives. Curr Hypertens Rep. 2016; 18: 72.

[20] Ahmadi-Abhari S, Sabia S, Shipley MJ, et al. Physical activity, sedentary behavior, and long-term changes in aortic stiffness: the Whitehall II study. J Am Heart Assoc. 2017; 6: e005974.

[21] Ashor AW, Lara J, Siervo M, et al. Effects of exercise modalities on arterial stiffness and wave reflection: a systematic review and meta-analysis of randomized controlled trials. PLoS ONE 2014; 9: el10034.

[22] Burr JF, Beck JL, Durocher JJ. The relationship of high-intensity cross-training with arterial stiffness. J Sport Health Sci. 2019; 8: 370-375.

[23] Johnson CP, Baugh R, Wilson CA, et al. Age related changes in the tunica media of the vertebral artery: implications for the assessment of vessels injured by trauma. J Clin Pathol. 2001; 54: 139-145.

[24] Miyachi M. Effects of resistance training on arterial stiffness: a meta-analysis. Br J Sports Med. 2013; 47: 393-396.

[25] Evans W, Willey Q, Hanson ED, et al. Effects of resistance training on arterial stiffness in persons at risk for cardiovascular disease: a meta-analysis. Sports Med. 2018; 48: 2785-2795.

[26] Ceciliato J, Costa EC, Azevêdo L, et al. Effect of resistance training on arterial stiffness in healthy subjects: a systematic review and meta-analysis. Curr Hypertens Rep. 2020; 22: 51.

[27] Sardeli AV, Gáspari AF, Chacon-Mikahil MP. Acute, short-, and long-term effects of different types of exercise in central arterial stiffness: a systematic review and meta-analysis. J Sports Med Phys Fitness 2018; 58: 923-932.

[28] Figueroa A, Okamoto T, Jaime SJ, et al. Impact of high- and low-intensity resistance training on arterial stiffness and blood pressure in adults across the lifespan: a review. Pflugers Arch. 2019; 471: 467-478.

[29] Goeder D, Böhm B, Oberhoffer R, et al. Postexercise changes in peripheral and central blood pressure during a 24 -hour ambulatory blood pressure monitoring in healthy young men. J Sports Med Phys Fitness 2019; 59: 1593-1598.

[30] Aengevaeren VL, Eijsvogels TM. Coronary atherosclerosis in middle-aged athletes: Current insights, burning questions, and future perspectives. Clin Cardiol. 2020; 43: 863-871. 
[31] Koshiba H, Maeshima E. Influence of detraining on temporal changes in arterial stiffness in endurance athletes: a prospective study. J Phys Ther Sci. 2015; 27: 3681-3684.

[32] Tamási L, Miksi Á, Kardos Z, et al. Musculoskeletal relevance of obesity: a new approach to an old topic. [Az elhízás mozgásszervi vonatkozásai: egy régi téma új megközelítésben.] Orv Hetil. 2019; 160: 1727-1734. [Hungarian]

[33] Raschke S, Eckel J. Adipo-myokines: two sides of the same coin - mediators of inflammation and mediators of exercise. Mediators Inflamm. 2013; 2013: 320724.

[34] Planavila A, Redondo I, Hondares E, et al. Fibroblast growth factor 21 protects against cardiac hypertrophy in mice. Nat Commun. 2013; 4: 2019

[35] Chow WS, Xu A, Woo YC, et al. Serum fibroblast growth factor-21 levels are associated with carotid atherosclerosis independent of established cardiovascular risk factors. Arterioscler Thromb Vasc Biol. 2013; 33: 2454-2459.

[36] Lee SY, Burns SF, Ng KK, et al. Pulse wave velocity is associated with increased plasma oxLDL in ageing but not with FGF2 1 and habitual exercise. Antioxidants (Basel) 2020; 9: 221.

[37] Inoue K, Fujie S, Hasegawa N, et al. Aerobic exercise traininginduced irisin secretion is associated with the reduction of arterial stiffness via nitric oxide production in adults with obesity. Appl Physiol Nutr Metab. 2020; 45: 715-722.
[38] Currie KD, Thomas SG, Goodman JM. Effects of short-term endurance exercise training on vascular function in young males. Eur J Appl Physiol. 2009; 107: 211-218.

[39] Donley DA, Fournier SB, Reger BL, et al. Aerobic exercise training reduces arterial stiffness in metabolic syndrome. J Appl Physiol (1985). 2014; 116: 1396-1404.

[40] Haskell WL, Lee IM, Pate RR, et al. Physical activity and public health: updated recommendation for adults from the American College of Sports Medicine and the American Heart Association. Med Sci Sports Exerc. 2007; 39: 1423-1434.

[41] Whyte LJ, Gill JM, Cathcart AJ. Effect of 2 weeks of sprint interval training on health-related outcomes in sedentary overweight/obese men. Metabolism 2010; 59: 1421-1428.

[42] Vlachopoulos C, Aznaouridis K, Terentes-Printzios D, et al. Prediction of cardiovascular events and all-cause mortality with brachial-ankle elasticity index: a systematic review and metaanalysis. Hypertension 2012; 60: 556-562.

(Harangi Mariann dr., Debrecen, Nagyerdei krt. 98., 4032 e-mail: harangi@belklinika.com)

\section{"Mens sana in corpore sano." (Ép testben ép lélek.)}

A cikk a Creative Commons Attribution 4.0 International License (https://creativecommons.org/licenses/by/4.0/) feltételei szerint publikált Open Access közlemény, melynek szellemében a cikk bármilyen médiumban szabadon felhasználható, megosztható és újraközölhető, feltéve, hogy az eredeti szerző és a közlés helye, illetve a CC License linkje és az esetlegesen végrehajtott módositások feltüntetésre kerülnek. (SID_1) 